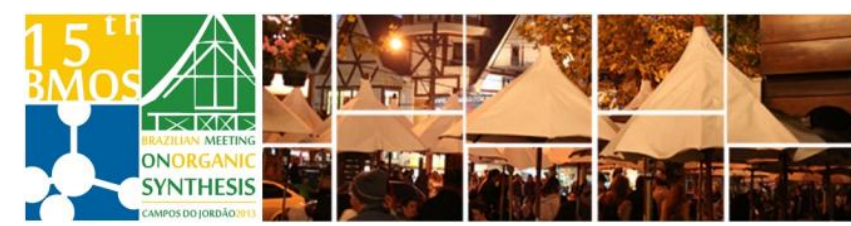

\title{
Selective semi-synthesis of dihydrocucurbitacin B glycosides
}

\author{
MOROTTI, A. L. M. ${ }^{1}$; ZIMMERMANN, L. A. ${ }^{1}$; MACHADO, V. R. ${ }^{1}$; SCHENKEL, E. P. ${ }^{1}$; \\ BERNARDES, L. S. C. ${ }^{1}$ \\ ${ }^{1}$ Programa de Pós-Graduação em Farmácia- UFSC, Florianópolis, SC. \\ *ilianscb@ccs.ufsc.br
}

\begin{abstract}
Keywords:
Cucurbitacins,

cucurbitacin
\end{abstract}

\section{INTRODUCTION}

Cucurbitacin glycosides are natural compounds which have gained attention due to their biological activities, mainly against different cancer cells ${ }^{(1)}$. Our research group has been investigating the preparation of cucurbitacin glycosides by semisynthesis, considering the difficulty of obtaining them from natural sources.

\section{RESULTS AND DISCUSSION}

DHB acceptors were prepared in order to ensure glycosylation of only one position. Initially, DHB (1), isolated form roots of Wilbrandia ebracteata, was selectively acetylated in C- 2 or oxidized in C- $16^{(2)}$ to give the compounds $\mathbf{2}$ and $\mathbf{3}$, respectively (scheme 1).

Scheme 1. Selective protection of C- 2 and C-16 of DHB.

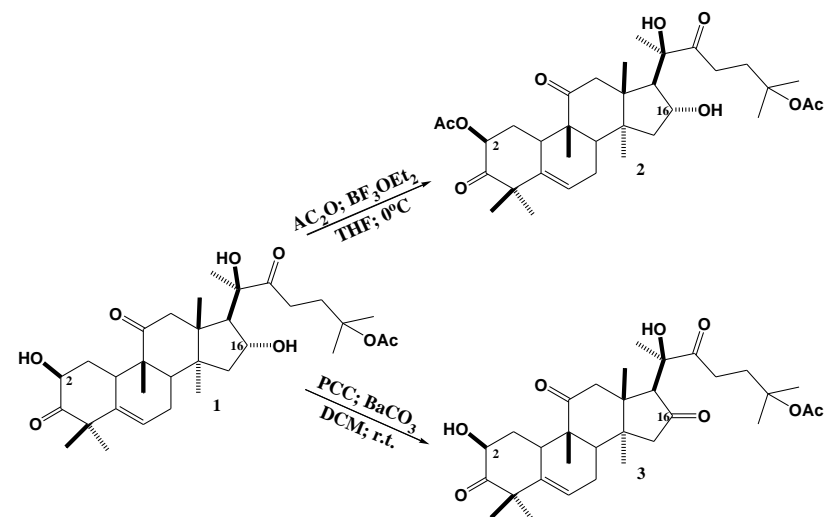

On the other hand, compounds $7 \mathbf{a}-\mathbf{b}$ were prepared according to literature ${ }^{(3,4)}$ from D-glucose $(\mathbf{4 a})$ and Dgalactose (4b), commercially obtained (Scheme 2 ).

Scheme 2. Synthesis of trichloroacetimidate donors.

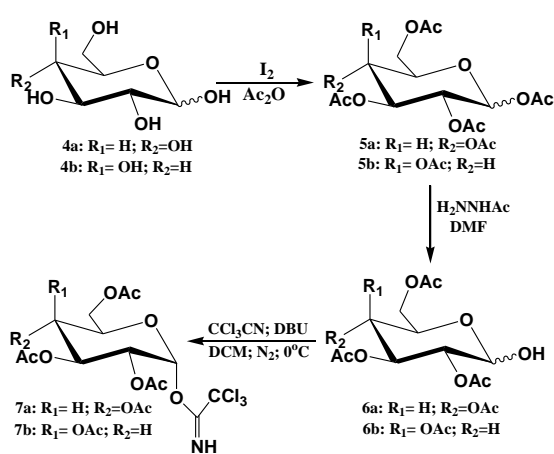

$15^{\text {th }}$ Brazilian Meeting on Organic Synthesis - 15 $5^{\text {th }}$ BMOS - November 10-13, 2013 - Campos do Jordão, Brazil
The acceptors $\mathbf{2}$ and $\mathbf{3}$ were submitted to glycosilation reactions with the glycosidic donors $7 a$ and $\mathbf{7 b}$, catalyzed by TMSOTf (Scheme 3 ).

Scheme 3. Glycosylation reactions with DHB acceptors.
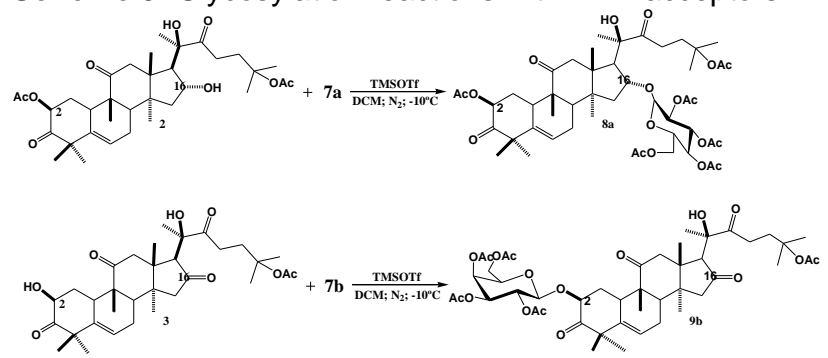

\section{CONCLUSION}

The proposed route allowed the achievement of DHB glycosides and their citotoxic activity will be investigated. Other glycosidic units are being used for the synthesis of new derivatives.

\section{ACKNOWLEDGEMENTS}

We would like to thank FAPESC and CNPq for the financial support.

\section{REFERENCES}

${ }^{1}$ Chen, J. C.; Chiu, M. H.; Nie, R. L.; Cordel, G. A.; Qiu, S. X. Natural Product Report. 2005, 22, 3, 386-399.

${ }^{2}$ Lang, K. L.; Silva, I. T.; Zimmermann, L. A.; Machado, V. R.; Teixeira, M. R.; Lapuh, M. I.; Galetti, M. A.; Palermo, J. A.; Cabrera, G. M.; Bernardes, L. S. C.; Simões, C. M. O.; Schenkel, E. P.; Caro, M. S. B.; Durán, F. J. Bioorganic \& Medicinal Chemistry. 2012, 20, 3016-3030.

${ }^{3}$ Kartha, K. P. R.; Field, R. A. Tetrahedron. 1997, 53, 34, 11753-11766.

${ }^{4}$ Ren, T.; Zhang, G.; Liu, D. Tetrahedron Letters. 2001, 42, 6, 1007-1010

${ }^{5}$ Cheng, H.; Cao, X.; Xian, M.; Fang, L.; Cai, T. B.; Ji, J. J.; Tunac, J. B.;

Sun, D.; Wang, P. G. Journal of Medicinal chemistry. 2005, 48, 2, 645-652. 